\title{
HUMAN RIGHTS AND THE EDUCATIONAL ROLE OF TECHNOLOGIES DURING THE COVID-19 PERIOD
}

\begin{abstract}
The current health emergency, linked to the Covid-19 pandemic, is bringing out strengths and weaknesses in the education and training system in all affected countries, one of these concerns the relationship between human rights and digital technological innovation. For this reason it is now necessary to rethink in the light of the tragic experience of Covid-19 new parameters of education and to orient the pedagogical perspective in an ethical-anthropological and legal dimension that pays attention to the person, his needs and not. More only to the techniques of innovation and methodological and digital experimentation which, without placing the person in the relationship at the center, will never be able to guarantee human rights and protect the dignity of the person.
\end{abstract}

KEYWORDS: human rights, digital technologies, education, education, training

\section{THE ROLE OF EDUCATION DURING THE PANDEMIC}

In the context of this work, Maritain's words resound more timely than ever: "Education cannot escape the problems and difficulties of philosophy, and first of all it is obliged to answer the question 'what is man?'» (Maritain, 2001, p. 63). 
The current health emergency, linked to the Covid-19 pandemic, is bringing out strengths and weaknesses in the education and training system in all affected countries, one of these concerns the relationship between human rights and digital technological innovation. Educational institutions, at all levels, have suffered a sharp discontinuity in the way of teaching teaching, which could create significant problems in the medium and long term. Over $80 \%$ of university students were able to benefit from online lessons, with high levels of attendance; about $95 \%$ of the universities have activated remote exam methods and over 26 thousand students have so far graduated (Caligiuri, 2020, pp. 33-40). These statistics lead us to question ourselves with respect to the far from negligible percentage of the excluded, i.e. students who have not been able to take advantage of the same educational-training opportunities as other students and therefore the right to study, education and training which are human rights fundamental aspects of the person as such (Indellicato, 2020).

So we ask ourselves how to intervene to include the excluded who represent the most fragile part of our society?

Rethinking education today, in the light of the tragic experience of Covid-19, means orienting the pedagogical perspective in an ethicalanthropological and legal direction that pays attention to the person, their needs, their needs and no longer just to innovation techniques and methodological and digital experimentation. It is necessary to rediscover "the person in relationship" as the only center of interest and to design interventions on him that protect his dignity, the value of diversity, to guarantee each and every one equal opportunities for training and the best of good. We must take the opportunity to put forward significant considerations and proposals for education and training for the future of the generations who must be able to fully realize their humanity, their human rights (Indellicato, 2020, p. 171).

Education is fundamental and indispensable for the realization of other human rights, what happened in this emergency period, I refer to the closure of schools, must make us reflect on the fact that in many countries of the world the rights of children not only with regard to education, but also with regard to nutrition, health and safety. 
In a recent survey, UNICEF stated that the more children do not attend school, the less likely they are to return, thus calling into question the right to study and education (Unicef, 2020).

Several technology companies have provided suggestions and solutions to parents and teachers to offer alternative home learning opportunities, such as Dad, which are effective but not entirely valuable as many children from low-income families cannot benefit from these modalities. In our country, adequate and equal development opportunities for everyone are not ensured and there are numerous discriminations that the most disadvantaged children face every day, especially if they come from poor families. In this regard, Save the Children 2014b has developed in Italy «an Educational Poverty Index (IPE), for the construction of which 14 indicators were used. Of these, 7 have the child as their unit of analysis» (Save the Children, 2014b).

The IPE represents an interesting attempt not to rely only on the family, but also to refer to the offer and degree of coverage of educational services, precisely because the child must be considered the recipient of resources and services in the first person. And in this regard, other indicators should be considered: number of children who enjoy educational, cultural and sporting opportunities such as theater, cinema, concerts, visits to exhibitions / museums, monuments and archaeological sites, use of the Internet, reading of books. The Educational Poverty Index showed that in the Italian regions where the greatest number of children in (material) poverty live, the level of educational poverty is higher in terms of both the presence and quality of services, and the participation of children in activities recreational and cultural (Bosisio, Vincenti, 2018, p.193). The first goal of the Agenda 2030 is to defeat poverty «despite the fact that the share of the global population living in extreme poverty dropped to $10 \%$ in 2015 (compared to $16 \%$ in 2010 and $36 \%$ in 1990), the world is not on track to end poverty by 2030 . Figures as of 2015 show that 736 million people are living on less than $\$ 1.90$ a day. The majority of these are found in sub-Saharan Africa. In 2018, 55\% of the global population did not have access to social protection» (ASviS Report 2019, p.19). In this emergency moment, Save the Children has issued a manifesto entitled "Let's rewrite the future, education and opportunities 
for the most vulnerable children", all this because the Covid-19 emergency is putting the right to education of many children at even greater risk and their future. With distance learning, many children have remained behind without being able to receive education and follow lessons, without receiving help and this could cause the permanent interruption of their studies (Save the Children, 2020).

We must not forget that human rights such as the right to education, education, study, equality are nothing but conditions that allow man himself to develop as a man and society to develop as a human. When on the basis of specific interests, those who hold some power try to cancel some of these attributions or conditions, then there is a risk that "life loses its value or is wrecked" (Corradini, Mari, 2019; Corradini, 1984). Among the solemnly recognized rights there is the right to education and the Universal Declaration in art. 26 states that «Everyone has the right to education [...]. Education must aim at the full development of the human personality and the strengthening of respect for human rights and fundamental freedoms [...]. Parents have, as a priority, the right to choose the kind of education to be given to their children» (Universal Declaration of Human Rights of 10 December 1948, art. 26, paragraph 2). Jean Piaget in a comment on art. 26 of the Universal Declaration of Human Rights stated that the right to education is nothing more than the right of the individual to develop according to the possibilities available to him with the obligation for society to transform these possibilities into actual achievements (Piaget, 1974).

The right to education, in the Declaration of Human Rights of ' 48 , is a fundamental human right and is recognized as a source and condition of respect for all other human rights and is the sine qua non for people to fully develop their own intellectual and moral abilities, a right that all society, the family and school in particular, and all the other training agencies in the area must take on board. The right to education is and must be a right to lifelong learning, as already explained in the 1972 Faure Report in which it is stated: "The educating community implies that the means are made available to every citizen free and permanent. to educate oneself, to form oneself, to cultivate oneself» (Unesco, 1972, p. 253). 


\section{DISTANCE TEACHING OR DISTANCE FROM TEACHING?}

Distance teaching is undoubtedly solving the underlying problems, as happened during the emergency period of Covid-19, but, by its very nature, it cannot successfully deal with the significant details of the intrinsic difficulties in teaching itself: first of all it requires the presence technical means and the ability to use them, albeit on loan, as underlined by the commitment of the Ministry of Education. This teaching requires those responsible for compulsory schooling in the presence, able to accompany pupils in their purely academic duties and also capable of managing the use of digital devices; very often pupils are orphans of parental computer skills and, therefore, are forced to double their work which automatically becomes fatigue.

Multimedia must be characterized by a significant educational depth aimed at a significant formative teaching (Rivoltella, 2000, pp. 219-258).

In the presence school, a relational dynamic is activated that is free and open, generative and capable of allowing one's authentic humanity to be fruitful in educating. In taking care of the other, the educator, according to Buber, takes care of man as such and makes it possible for him to unfold freely and creatively, thus allowing the pupil to provide himself and to discover his own belonging to a further dimension (Buber, 2017), so that alleducational action is aimed at its full humanization (Evans, 2014, p. 44).

The digital divide between those who have the possibility to use online technology and those who do not have it is a source of indirect discrimination and this problem requires urgent measures because it seriously endangers the denial and therefore the enjoyment of the human rights of children. themselves, such as the right to study, education and to have equal educational opportunities.

The educational role and the wise use of technologies must be able to contribute to the real development of those capabilities which, according to Nussbaum, translated into action, lead to the full flowering of humanity in all its expressions without running the ethical risk of improper use of the same. technology that from a means becomes an end, as has unfortunately often happened (Rivoltella, 2011, pp. 107-119). 
In some cases, distance learning has become a real "distance from teaching", as recently highlighted by some statistics, because it has not allowed the affirmation of equal educational and training opportunities and has not been able to compensate for all that the school represents, although constituting, in an emergency moment such as that of Covid-19, a usefulness because it has in some way allowed the students to maintain the bonds, certainly different from those that occur when one is in presence, in a learning process that is above all characterized by questions, looks, gestures, by that human warmth which is unfortunately lacking and which is fundamental in an educational relationship that wants to help grow and shape the personality of young people by giving everyone equal opportunities.

There were many problems related to distance learning between teacher and learner during this emergency period, for example the lack of involvement on the part of the teacher in teaching activities, or the lack of attention in being able to follow the teachers during the webinar lessons. We must not forget, as the Russian psychologist Lev Vygotskij argues, that learning is conditioned by the social, affective-relational climate, by personality, by attitude, and that mental development is a process of internalization of cultural forms (Vygotskij, 1987). Therefore teachers need to be concerned with the social climate, variety in learning activities, create opportunities for learners participation, take care of students' personal development; all actions that can only take place through face-to-face teaching.

An old proverb says: "They speak to me and I forget; they make me see and hear and remember; they make me try and I understand", we talk about the learning by doing technique, we learn by experiencing what we are taught. Dewey writes: «The great thing to keep in mind when various forms of active employment are introduced into schools is that through them the whole spirit of it is renewed. It can then become in harmony with life, become the home of the boy, where he learns by living, instead of being reduced to a place where lessons are learned, which have an abstract and remote relationship with some possible life that he will have to live in the future» (Dewey, 1985, p. 10).

Consequently, if the teacher is concerned with directly ascertaining the truth of his statements in an operational way, not only does he keep attention, a very important faculty in the educational-training process, but greatly 
facilitates their understanding. Weil writes: «The real goal is the almost unique interest of studies and that of training the faculty of attention, even if today it seems to be ignored» (Weil, 2008, p. 191). This makes us understand that knowing is not enough to be able to teach, but it is necessary to integrate knowledge and experience, which cannot be done through a screen, if there is less teaching in the presence, there is less action and attention.

Teaching oneself to question oneself about the possible uses of what is being learned prepares the student to be able to better select the value and importance and, consequently, to study with greater taste and profit. If a teacher is able to establish a positive relationship of mutual trust whereby the pupil knows he can express his desires and can express his difficulties without being humiliated or neglected, he will feel more stimulated to learn, knowing that he can count on a person who takes his problems to heart, in this sense the basic trust Erikson talks about is important, then what the teacher says, or proposes to do, acquires the value of an important thing for the benefit of the learning process (Erikson, 1968).

The empathic approach represents an essential condition in the educational relationship because the person who grows and who lives his maturation process needs trust, hope (Catalfamo, 1996), love, and, knowing that he is esteemed, loved can, time, "love", bet on oneself and actively participate in the educational process to become better. «Reflecting 'as in a mirror' the empathizing gaze opens to those who consent to be seen and known in the love of predilection, a vision of personal truth and a new love of one's own good that enable the subject to know himself, to choose himself and to prefer himself, in turn, in order to an existential project that interprets and carries out the singular destiny of each one» (Bellingreri, 2005, p. 161).

Technologies can be of help in the field of education and training to the extent that they retain the connotation of being a means and never turning into an end. Those who use technology, as an end and not as a means, transforming it into a technique, are forced to lose and cancel control of the learning process and become, with excessive damage to the brain, dominated by the digital, almost bordering on a pathology that it manifests itself precisely with the unlimited use of both information technologies and new media. This new psychopathology was discovered and theorized by neuroscientist Manfred Spitzer. The German scholar argued that «if we limit ourselves to chatting, 
tweeting, posting, surfing on google [...] we end up parking our brains, now unable to reflect and concentrate. The increasingly intensive use of computers discourages study and learning and, conversely, encourages our children to stay in front of electronic games for hours. Not to mention the social networks that offer toxic substitutes for true friendships, weakening the ability to socialize in reality and favoring the onset of depressive forms» (Spitzer, 2013, p. 13).

Technological means can help teaching, but they can never replace it because true teaching is above all relationships and this can only take place in the school where interpersonal relationships are important for the purpose of a process of humanization that can never occur with only one distance learning. The use of educational technologies can be accepted as valid from a pedagogical and legal point of view only if it serves to guarantee human rights for all children and each child, and instead does not cause discrimination and inequality.

As widely emphasized also by Vygotsky's theory, educational practice must enhance the interactive aspect between educator and learner, between student and student, between students and adults, because without social interaction, internalization and learning would never take place. The school atmosphere promotes and encourages the mutual interaction of the members of the entire educational community (Vygotsky, 1969).

Faced with telematics, the increasingly sophisticated technologies, the hyperbolic evolution of the means of communication, man is claiming his right not to be contaminated in his essence. Since the most powerful means available to man is communication, it is on it that the teacher must leverage to put complexity in order.

Today, someone writes, for the innovative power, that communication is called "perestroika" and everyone knows that the true meaning of "perestroika" is metanoia, that is, the change of man, of anthropological qualities.

However, for this change to take place, a valid education must be implemented. An education is valid when it places "the person" at the center; the term education comes from the Latin educere which means "to bring out" what is inside, and to educate (cultivate), this means that the teacher must draw on and bring out what is inside the child, those faculties, potentialities that constitute his essence, its nature and cultivate them to their full bloom. 
In school language, therefore, education means implementing what is potential, what is "germ" (aptitudes, abilities, faculties, etc.). Education in the authentic sense is that which tends to cultivate and promote the humanization of the young in the expression of all his or her potential (Nussbam, 1997).

In the past century it was stated: education must conform to the universal principles of reason, that is, to accustom the educator to live convenienter naturae, and live convenienter rationi.

At that time, teachers were guilty of rigorism. Today, veterans of the social revolutions of the sixties and seventies, who have set aside the pedagogy of the negative (education through obedience, authority), there is a tendency to embrace pedagogy that is essentially based on a methxic and dialogic relationship and which is not he deduces behaviors from general norms, but drawing inspiration from them and fundamental values, «he incarnates himself in situations and calls the individual to the difficult and irreplaceable job of man» (Ducci, 1992, p. 28).

\section{THE PANDEMIC EMERGENCY AND A NEW EDUCATIONAL SENTIMENT}

The teacher, to be a teacher in the concrete of what is possible, must acquire the ability to discern situational opportunities, mastering the skills of mediation that knows how to practice the logic of communication in order to gain the context of the learner and with it respect and esteem. The greatest threat to man today is selfishness, which risks being much more deleterious than in the past. Love, oblativity cannot consider only the neighbor, the contemporary, closer, but humanity far and in the future. It is therefore essential that the teacher, in order to effectively and efficiently perform the task required of him by the user, has a clear and solid culture of the subject and a renewed professionalism consisting in the ability to grasp the needs, aspirations, trends of the child. In other words, the teacher must acquire a professional preparation that gives him, in the eyes of society, the "style" of teacher of today's society.

In modern society, characterized by the premature aging of every cultural branch due to the intensification of scientific research, the continuous emergence of new life and work situations, the need arises for an education for 
"change". Today we are faced with an essentially scientistic and technological society. This society does not always respect the same laws of nature and often forgets Bacon's admonition that "nature is controlled by obeying it". It is certainly a challenge, nature rebels, responds with pollution, with the disintegration of the ego when the interiority of man is violated.

It cannot be ignored how in the long quarantine period the weakest and most fragile groups of students were neglected who could not use the various digital means such as pc, tablets, and even the internet connection (wifi), or because they belong to large families low-income with several children and only one pc available or because they reside in countries and districts of our territory where the connection is absent, so as not to think about the enormous difficulties that the diversables and their families have encountered who in any case have committed themselves, however much in their possibilities, in certainly unprofessional help and assistance. The disadvantaged have remained more disadvantaged with the risk of losing them permanently, and how can we speak in this case of guaranteeing human rights? When did the same technologies and their use discriminate by not providing equal training opportunities?

The emergency is the occasion from which a "new educational sentiment can arise that must first of all be assumed and then carried out with care" (Guerra, 2020). But it is also an opportunity to rethink education and human rights and new technological paradigms and to question the role of the school and its purposes, without neglecting a strong appeal to politics that must consider education a priority, a fundamental human right. In which to invest, right away, not thinking of a restart only in terms of organization and social distancing, which are useful conditions for safeguarding the psycho-physical well-being of students, but which have little to do with the educational mission, which in its specificity it is to guarantee the right to study, education, training, education of all children, as fundamental, inalienable and non-negotiable human rights of the person's being. The organization of spaces or the teaching of techniques or social distancing cannot and should not be understood as an educational-training discourse, or even worse, thinking about projects that can be spent in the market and in the logic of the market, because this would mean selling off the pedagogical discourse to the reasons of the prevailing economism, distorting the logic of education and training. Bruni writes: 
«The relationship between the sphere of training and life lived is very close: education, in fact, is such only and only if it is useful in life and for life. The difficulty lies in translating these pedagogical principles into pedagogical practice, that is, in realizing the educational power aimed at the acquisition by young people of the ability to use knowledge, without fragmentation, without specialization, without technicality» (Bruni, 2008, p. 102).

Unfortunately, the DAD has done away with the essential task of education which is to ensure that, as far as possible, diversity does not become inequality and that it looks to that training process that must also respond to the need for inclusion as a factor essential for stemming early school leaving and which represents one of the most important challenges of contemporary education. In fact, the binomial inclusion-education arises, today, in an imperative way, as the pivot of an idea of training that is necessarily aimed at the maieutic objective of developing the capabilities (Sen, 1999) of each and every one, precisely to substantiate the educational project of a democracy as an authentic form of associated and inclusive life (Corsi-Sani, 2004).

The ability to "include" is in fact a primary need of civil society and at the same time the criterion that qualifies education as a fundamental human right.

In this scenario, the School, as an institution dedicated to training, is called to fully realize the being of children and their rights, to support and encourage them, as Kant had already stated (Kant, 2006, p. 583). The German philosopher supports us in this sense with the reflection carried out in the Doctrine of the Ethics Method of the Metaphysics of Customs to the extent that it offers us the opportunity to rethink the strategic role of the educator in the training process. In this regard he writes: «A good example (exemplary conduct) should not serve as a model, but only to prove that what is in conformity with duty is practicable. Therefore it is not the comparison with any man (as he is), but rather that with the idea (of humanity) of how he must be, and ultimately the confrontation with the law that must offer the master the infallible criterion for his teaching» (Kant, 2006, p. 583).

The good teacher is not the one who possesses all the knowledge but is the one who knows how to enter into a positive and empathic relationship with his learners knowing full well that it is impossible to know all the knowledge keeping in mind the lesson of Socrates. 
Hence the opportunity for a significant inversion of perspective capable of making the person and the community be considered from the point of view of duties even before rights, as Simone Weil says when he states that "the notion of obligation overrides that of right, which it is relative and subordinate to it. A right is not effective in itself, but only through the obligation to which it corresponds; the effective fulfillment of a right does not come from whoever possesses it, but from other men who recognize that they are obliged to something towards it» (Weil, 1990, p. 13).

\section{Conclusions}

The future of education is linked, in my opinion, to three fundamental pillars:

- fraternity

- an inclusive school for the equality of equal educational opportunities

- fair and supportive justice.

Fraternity, in fact, is a form of reciprocity that founds justice as a key to taking care of the other.

Inclusion as a value that could heal the wounds of a school that often marginalizes and disperses its children and at the same time reveals the poverty, malaise, radical inequality and social suffering of its students.

And finally, in such a context, equitable rather than egalitarian justice is indispensable, that is, justice capable of weighing up efforts to bridge differences, an indispensable condition for civil coexistence.

In my opinion, these three fundamental conditions are essential factors for educating human rights and at the same time guaranteeing equal training opportunities, without discrimination, marginalization and suffering; and educational technologies must give help insofar as they serve the educational needs of all children and of each learner also for the purpose of an inclusion that predisposes to a civil and peaceful coexistence.

To future generations we would like to responsibly leave a world in which, in addition to natural resources, they can also count on human resources, achieved through a full human formation to respond adequately to the numerous historical and epochal challenges of our time. 


\section{References}

Bellingreri A. (2005). Per una pedagogia dellempatia, Vita e Pensiero, Milano. ISBN 9788834311509.

Bosisio R., Vincenti A. (2018). “They dance alone. I minori tra società e diritti sociali”, in L. d'Alessandro, A. Montanari (a cura di), Diseguaglianze e crisi della fiducia. Diritto, politica e democrazia nella società contemporanea, FrancoAngeli, Milano. ISBN 9788891767646.

Bruni E. M. (2008). Pedagogia e trasformazione della persona, PensaMultimedia, Lecce. ISBN 9788882325916.

Buber M. (2017). Discorsi sulleducazione, a cura di Anna Aluffi Pentini, Armando, Roma. ISBN 8860814510.

Caligiuri M. (a cura di) (2020). Post Covid-19. Analisi di Intelligence e Proposte di Policy 2020-2021, Rubbettino, Soveria Mannelli.

Catalfamo G. (1986). Fondamenti di una pedagogia della speranza, La Scuola, Brescia. ISBN 9788835078371.

Corradini L., Mari G. (2019). Educazione alla cittadinanza e insegnamento della Costituzione, Vita e Pensiero, Milano. ISBN 9788834337943.

Corradini L. (1984). "Per una pedagogia dei diritti umani”, in Vita e Pensiero, n.5, Vita e Pensiero, Milano 1984. ISSN 0042-725X.

Corsi M., Sani R. (a cura di) (2004). L’educazione alla democrazia tra passato e presente, Vita e Pensiero, Milano. ISBN 9788834311240.

Dewey J. (1985). Scuola e società, tr.it., La Nuova Italia, Firenze. ISBN 9788899900328.

Ducci E. (1992). Approdi dellumano. Il dialogare minore, Anici, Roma. ISBN 9788873460756.

Erikson E. (1968). Introspezione e responsabilità, tr.it., Armando, Roma. ISBN 9781080159994.

Evans J. (2014). Filosofia per la vita, tr.it., Mondadori, Milano.

Guerra M. (2020). “Dall'emergenza può emergere un nuovo sentimento educativo”, in Sole 24 ore, 13 maggio in https://scuola24.ilsole24ore.com/art/scuola/2020-05-12/ dall-emergenza-puo-emergere-nuovo-sentimento-educativo-185410. php? uuid $=\mathrm{ADrFJ} 8 \mathrm{P} \#: \sim$ :text $=$ Dall'emergenza $\% 2 \mathrm{C} \% 20$ dunque $\% 2 \mathrm{C} \% 20$ pu\%C3\%B2,e\%20poi\%20maneggiato\%20con\%20cura.\&text=Ma\%20la\%20cura\%20 deve\%20essere,un\%20senso\%20educativo $\% 20 \mathrm{e} \% 20$ didattico.

Indellicato R. (2020). La dispersione scolastica nel terzo millennio. Analisi e prospettive pedagogiche tra vecchi bisogni e nuove sfide, Pensa Multimedia, Lecce. ISBN 9788867607396. 
Kant I. (2006). Metafisica dei costumi, tr.it., Bompiani, Milano. ISBN 9788845257094.

Maritain J. (2001). La filosofia delleducazione, tr. it., La Scuola, Brescia. ISBN 9788835099512.

Nussbam M. (1997). Coltivare l'umanità, tr.it., Carocci, Roma. ISBN 9780674179493.

Piaget J. (1974). Dove va l'educazione, tr.it., Armando, Roma.

Rapporto ASviS (2019).

Rivoltella P. C. (2000). La multimedialità, in C. Scurati (a cura di), Tecniche e significati. Linee per una nuova didattica formativa, Vita e Pensiero, Milano. ISBN 9788834305928.

Rivoltella P. C. (2011). Saggezza digitale: l'educazione mediale una sfida tra etica e scuola di cittadinanza, AA. VV., Educare tra scuola e formazioni sociali, La Scuola, Brescia.

Save the Children, (2014b).

Save the Children, (2020) in https://www.savethechildren.it/press/la-povert\%C3\%A0-educativa-ai-tempi-del-coronavirus-bambini-e-adolescenti-intrappolati-tracrisi.

Sen A. (1999). Commodities and Capabilities, Oup India, New Delhi. ISBN 9780195650389.

Spitzer M. (2013). Demenza digitale, tr.it., Corbaccio, Milano. ISBN 9788863805918.

UNESCO (1972). Rapporto sulle strategie delleducazione, tr.it., Armando, Roma.

Unicef (2020), in https://www.unicef.it/doc/6834/progetti-servizio-civile-unicef-italia-2020.htm Vygotskij L. (1987), Il processo cognitivo, tr.it., Bollati Boringhieri, Torino.

Vygotskij L. (1969). Psicologia e pedagogia, tr.it., Editori Riuniti, Roma. ISBN 9788835925330 .

Weil S. (2008). Attesa di Dio, tr.it., Adelphi, Milano. ISBN 9788845923111.

Weil S. (1990). La prima radice. Preludio a una dichiarazione dei doveri verso lessere umano, tr.it., Mondadori, Milano. ISBN 9788877107060. 